\title{
PROSPECTS FOR CHINA'S BRI AND STRATEGIC INFLUENCE IN THE POST-COVID-19 CENTRAL ASIA
}

\section{INTRODUCTION}

COVID-19 has put a significant strain on the Central Asian economies. Experts believe that the economic impact of the Pandemic could last longer than its direct health impact in the region. Besides internal weaknesses in its economic structure including low level of diversification and greater dependence over commodity and remittances, COVID-19 is a consequential externality for Central Asian economies with profound impact on its long-term economic planning and decision making. Rapid recovery from the economic slowdown is likely to stay as the priority in the post-Pandemic Central Asia which means greater inclination towards long-term economic projects like China's Belt and Road Initiative (BRI).

China's BRI is a $\$ 1.4$ trillion ambitious economic venture connecting Beijing to Europe through Central Asia and encourages regional countries to improve economic integration through regional connectivity. It helps China to actively demonstrate its transformation from a rule-taker to a potential rule-maker with greater role in global trade and governance. For China, BRI is part of its strategy to "stabilize in the east, gain strength in the north, descend to the south, and advance to the west." China's rapid defeat of the COVID-19 at home and phenomenal revival of its economic ascend amidst the pandemic encourages Beijing's efforts to extend support to the Central Asian countries and accelerate its progress over the landmark projects of BRI.

Central Asia, often tagged as the 'Buck of the Belt', holds crucial significance to BRI as the major transport corridor to lucrative markets like West Asia, Russia, and the European Union, in addition to its utility as a rich destination of natural resources. The region, which shares authoritarian values with the PRC, offers China the opportunity to use Central Asia as a 'strategic home-front', exploit its natural resources, and defend itself from the three evils threatening China's national interests i.e. terrorism, separatism, and extremism. Therefore, besides economic benefits, BRI improves China's strategic position in the region and serves to advance its vital strategic and political objectives.

On the other hand, BRI improves Central Asia's regional trade, connectivity, and overhauls its obsolete transport infrastructure. It helps the region to attract investment, improve job creation, and facilitate technology transfer to improve social welfare and accelerate economic growth in the region. Therefore, the growing economic uncer- 
tainty and lack of alternative amidst COVID-19 improves prospects for the rapid development of BRI in the Central Asian region. In this respect, China is committed to take measures for the development of the BRI projects as the top priority in the postPandemic Central Asia.

China's entry into Central Asia is guided by its geo-economic strategy that seeks to promote trade, secure energy supplies, explore markets, and build cross-border infrastructure to enhance regional connectivity. While China and Central Asia are connected through peace and war, trade and connectivity, history and intermarriages for centuries; however, the BRI is expected to transform the trans regional integration into an 'Iron Silk Road' with relative economic stability for the region in the postPandemic world.

The research paper is divided into five parts with part one explains the impact of COVID-19 over the Central Asian economies. The second part highlights the significance of BRI and Chinese investment in Central Asia in the post-Pandemic environment. In the third part, the paper explains the prospected rise in Chinese influence in post-Pandemic Central Asia, especially because of the BRI. The fourth part highlights major challenges to the implementation of China's BRI and its influence in Central Asia. Lastly in the fifth part, the paper presents policy recommendations to deal with the challenges presented to China's BRI and Central Asian economies.

The paper argues that the adverse impact of COVID-19 on ailing Central Asian economies increases prospects for China's BRI as a long-term source of economic recovery and its strategic influence in the Central Asian region. It answers the following questions; what is the impact of COVID-19 over the fledgling Central Asian economies? How COVID-19 does raise the significance of BRI for Central Asia and the region's importance in linking the Asian and European markets? How COVID-19 does increases China's geopolitical influence in the Central Asian countries? What are the major factors that provide impetus for China's desire to increase its influence in the Central Asian region? And finally, what are the major challenges to China's BRI in Central Asia amidst the COVID-19 crisis?

\section{THEORETICAL FRAMEWORK: BOURDIEU'S THEORY OF SYMBOLIC POWER, AND CHINA'S GEOPOLITICAL VISION}

Before employing the Bourdieu's theory of Symbolic Power in this article, it is important to understand the theoretical relevance of the term Geopolitics in China's growing influence in Central Asia and beyond under the ambit of BRI. BRI has remained an attractive economic enterprise which has gained approval in and participation among a large number of countries, especially in the developing world and for good reasons. This is because BRI offers these countries to assist them in expanding their international trade, reducing barriers to their access to regional and global markets, and therefore; at least in theory for now, it pledges to become a mutual enterprise of achieving a shared economic growth and development (Karlis et al., 2019: 7). However, China's visions for BRI extends far beyond geo-economics into a coherent strategy of making it an extended tool of Chinese geopolitics, especially in the Central Asian region which 
it tags as the 'Buck of the Belt' in the BRI. Besides its SREB, BRI also carries ahead its Maritime Silk Route that aims to ensure the security of its shipping lanes between East Asia and the Persian Gulf that also guarantees its energy security amidst the growing opposition to its geopolitical assertion in the South China Sea and beyond. However, the article focuses only on its SREB portion and its geopolitical imperatives for China and consequences for the Central Asian countries.

Steven Lukes define three major dimensions of power; first is the power of influence that wins conflict and shape decision-making; second is setting the agenda by limiting the alternatives; and third is shaping the preferences and behavior of others or their normality in short. Pierre Bourdieu's Theory of Symbolic Power explains the third dimension by suggesting that cultural roles are more dominant than economic forces in determining how the hierarchies of power are suited and reproduced across societies, and therefore, states in this study (Bourdieu, 1989). China's BRI in Central Asia is the economic manifestation of this symbolic power which is a rich geopolitical package to influence the Central Asian region against the other regional and extraregional contenders like Russia and the United States.

China, having linked Central Asia through institutions such as the Shanghai Cooperation Organization (SCO), is using its geoeconomic tools to foster its strategic and geopolitical influence in the region for a multitude of purposes. The article lists three fundamental imperatives that China could achieve using its BRI; gaining access to the European and West Asian markets, handing on Central Asian energy reserves and natural resources, and using it as a extended strategic home-front against the 'three evils' including terrorism, separatism, and religious extremism. By the measure of Bourdieu's Symbolic Power, the assumption suggests that China, with its ambitious and pro-active role, is bent on inevitably changing the global landscape not only in terms of economics and security outlook, but also in terms of the flow of ideas and normative influence which has fueled and became the corner stone of Chinese foreign policy during the COVID-19 pandemic where China tried to attract global audience with its initiatives like Health Silk Road, COVID Diplomacy, and special White Paper on 'Fighting COVID-19: China in Action' that builds a normative weight to China's symbolic profile in the region (Vangeli, 2018). In this way, as will be explained in the following portions, BRI is becoming a major tool for China by which it is developing its geopolitical profile in the region by multiplying the utilities of the projects and maximizing incentives for the pandemic-hit regional Economies.

\section{RESEARCH METHODOLOGY}

The article is concerned with the prospects of China's BRI and its resulting influence in the Post-COVID-19 Central Asia which makes it a qualitative study. However, the economic considerations and quantitative data used for the relative economic imperatives and implications of COVID-19 and BRI makes the study based on a mixed method which is being used to identify the relative significance and implications of COVID-19 in the Central Asian economies and its growing prospects for the BRI. The study collects data from both primary and secondary sources with a wide range 
of sources. For instance in the primary sources, data was extracted from the official policy documents of the People's Republic of China as well as those of the Central Asian governments. Also, the reports from the international financial and monetary institutions including the World Bank and IMF were used to record the official narrative. In secondary sources, data was gathered from books, journal articles, magazines, electronic and print media sources including newspapers.

Qualitative Content Analysis has discursively been applied in the paper to elucidate the influence of COVID-19 as a factor in necessitating BRI as the priority both for China and the Central Asian countries. For this purpose, statements from the Chinese officials have been used to understand the greater willingness in Beijing of accelerating the BRI projects and their geopolitical significance to China's strategic influence in the Central Asian region.

\section{COVID-19 AND ITS IMPACT ON CENTRAL ASIAN ECONOMY}

Central Asia is among the worst hit region of COVID-19 due to its weak response given the lack infrastructure and health facilities. The Global Health Security Index indicates the preparation of countries in terms of fighting the pandemic and finds that 73 percent of global population resides in countries with scores below 50 percent between the scale of 0 (absolutely not prepared) and 100 (well prepared) (Radjabov, 2020). Interestingly, no Central Asian country scored above 50 which show the weak response from the region to the pandemic leading to a range of adverse implications, especially on the regional economies.

Strict lock-down measures have prevented the virus from circulating and causing more deaths; however, these measures have severely plummeted economic activities across the region. Trade activities have declined with the disruption of demand and supply chain, reduction in global consumption has led to decline in oil and gas revenue, investment has plummeted, remittances have declined to a historical low, and socio-economic inequalities have exacerbated especially for the women, migrants, rural citizens, and the informal workers.

Since the first half of 2020, COVID-19 has collapsed the economic output of Central Asia. The Asian Development Bank suggests the economic crisis caused by the Pandemic could be the worst downturn the region has experienced in the 25 year since the region has transformed into a market economy. The World Bank in its report 'Europe and Central Asia Economic Updates' predicted a recession in 2020 with a poor growth rate of only -4.4 to -2.8 percent. Before the pandemic, the region was expected to grow at a dynamic higher rate which was curtailed by the Pandemic. For instance, before the pandemic, the prospected growth rate for Uzbekistan in specific was around 5.7 in 2020 and 6.0 percent in 2021; however, the rate of the economic projectile was 1.6 for 2020 and only 1.8 for the 2021 (Gupta, 2020).

In the first half of 2020, Kazakhstan saw a decline of 7.4 percent in its global trade and roughly 2.9 percent decline in GDP compared to same period in 2019. In fact, the number was around 10 percent with the members of the Eurasian Economic Union (EEU). It will see an increase in poverty from 8.3 percent rise to the 12.7 percent. The 
Center for Analysis of Economic Reforms and Communication (CAERC) in its report issued in August 2020 stated that Azerbaijan saw a decline of 8.6 percent in the first seven months of 2020 in a significant decline in exports to Turkey, and those to China and Russia rose in the meantime (CAERC, 2020). For Kyrgyzstan, a report by the ADB suggested that GDP declined by 10 percent with 90 percent decrease in tourism revenue in 2020 (COVID-19 in the Kyrgyz Republic, 2020: 13). Inflation in Tajikistan has rose by some 10 percent and a significant decline of GDP due to the decline of remittances that accounts for some 30 percent of it (Akhal-Teke, 2020). Turkmenistan which even denied the pandemic has reached the country by August is rather discreet about the actual figures pertaining to the economic impacts. However, it has stopped working on major industrial projects like the trans-Afghan TAPI gas pipeline, while people are getting unemployed due to an industrial halt (Akhal-Teke, 2020). Finally in Uzbekistan, the external trade turnover was reported to be around 19 percent or some $\$ 4.7$ billion in the first half of 2020 (Report of the State Committee, 2020).

In addition to this, remittances to the Central Asia shows a continuous decline by 20.1 percent in Kyrgyzstan, 22.3 percent in Tajikistan, and some 7 percent in Uzbekistan making a total decline of 23.8 percent or some $\$ 3.4$ billion, especially from Russia, to the entire region (COVID-19 in the Kyrgyz Republic, 2020: 7).

Just prior to the pandemic, Tajikistan borrowed $\$ 330$ million from China, in addition to a total of $\$ 1.5$ billion for major infrastructure development including highways which accounts for some 55 percent of its total public debt (Ibragimova, 2019). In the post-Pandemic engagement, the need for more financial assistance from China will rather grow.

The economic descend in Central Asia during the pandemic is mainly because of the three reasons; firstly, the containment measures taken by regional governments by closing border and halting supply lines have stopped cross border regional trade. Secondly, the decline in demand for natural resources and oil have declined the prices of oil commodities as well which has reduced exports revenue for the regional countries. Thirdly, the flow of remittances has declined significantly during the pandemic, especially from Russia and Europe. For instance, Kyrgyzstan and Tajikistan depends on remittances for some 30 percent of their GDP which is affected due to the loss of jobs and travel restrictions amidst the COVID-19.

Therefore, given the economic strain coupled with the challenges in revival of its economic growth, the Central Asian countries needs long-term economic initiative like China's BRI to ensure rapid economic revival in the post-Pandemic world.

\section{SIGNIFICANCE OF BRI AND CENTRAL ASIA}

China's BRI emerges as the turning point in Central Asia's Post-Soviet history in terms of its economic progress and development. In fact, this huge project was announced as the "One Belt, One Road" by the Chinese President Xi Jinping during his visit to Kazakhstan in 2013 (Chronology of China Belt and Road Initiative, 2015). $\mathrm{He}$ emphasized the significance of cooperation between China and Central Asia to build the 'Belt' part of the project. This is because Central Asia being the 'Buck of the 
Belt' is the destined as the major transport corridor for China's BRI which will connect China to the European markets. However, in addition to its role as the strategic highway for the 'Belt', China's BRI is likely to increase Central Asia's regional trade by developing its old transport infrastructure, bring more Chinese investment, improve the production capacity of regional countries, diversify their economy, and help the region regain rapid economic growth amidst the Pandemic.

China's advantages from Central Asia amidst the pandemic are driven by the significance of the region in imprinting BRI a successful story in the twenty first century. It remains central to Beijing's ambitions across the Eurasian supercontinent where BRI connects China to the Middle East, South Asia, Europe, and Russia. This reduces the dependence over the maritime routes which are vulnerable to the American threat.

Central Asia in itself holds crucial importance for China's strategic needs. For instance, its huge energy reserves such as hydrocarbon and mineral resources are important for China's economic growth and to run its industry. This thirst for natural resources runs from Afghanistan's rare-earth metals and natural gas of Turkmenistan to the oil and uranium deposits of Kazakhstan. In fact, China controls over one fourth of Kazakhstan oil production while also imports almost all the natural gas exports from Central Asia through the Central Asia-China gas pipeline.

This becomes more important when China relies for over half of its energy needs especially oil from the Middle East and around 80 percent of its imports are transported through seas. Therefore, Central Asia provide China a short, cost effective, and secure energy land corridor to ensure security of its energy needs in case of any conflict along the maritime routes in future.

Central Asia will host the most important economic corridor known as the 'ChinaCentral Asia-West Asia Economic Corridor' which runs from Urumqi in China through Tashkent, Bishkek, and Almaty touches Bandar Abbas in Iran, and passes through Caspian Sea in South Caucasus to reach Europe. Transportation along these lines across the region helps regional countries to gain huge financial benefits. For instance, Kazakhstan will get some $\$ 5$ billion annually as the transit fee for the transportation of goods passing through its territory to the European and other regional markets (Belt and Road Initiative, 2019).

Central Asian countries do not have direct access to the navigable waters which limits their ability to transportations of goods and trade. BRI under its connectivity projects such as railway lines and highways will improve the transport infrastructure enabling regional countries to rapidly transport goods and people with a better inter-regional and even intra-state transport systems. Some of these projects have been completed and are operational for the last few years. For instance, the Wahdat-Yovon railway line which was built by China under its BRI in Central Tajikistan is operational since August 2016. The same year, the Agren-Pap Tunnel was opened for traffic in Uzbekistan which has positive impact on transportation of goods and people (Yellinek, 2020).

On the other hand, BRI is expected to create more jobs, bring more investment and innovation to the Central Asian economies. In fact, currently China is the largest trade partner of almost all the Central Asian countries which will be doubled with the implementation of BRI. 
Moreover, the BRI includes a range of short and long-term projects ranging from the railroads, highways, pipelines, industrial parks, special economic zones, and gas pipelines which connects Central Asia to China's and other regional markets for its natural resources. One of the important features of BRI and its related benefits like loans and investment offered by Beijing is not conditioned to different social, political, and economic reforms like human rights or democratic freedom as often required by the Western powers (Sim, Aminjonov, 2020). Therefore, BRI is more attractive for the authoritarian regimes of Central Asian states and its immediate implementation to boost the regional economic flight is expected to bring more legitimacy and stability to the ruling elite.

\section{CHINA'S BRI AND INFLUENCE AMIDST COVID-19}

China has taken full benefit of the Pandemic to improve its relative position and influence in Central Asia. The 'Visions and Actions on Jointly Building the Silk Road Economic Belt and Maritime Silk Road', the main official strategic document by China issued in March 2015, defines the objectives of BRI which includes 'promoting the orderly and free flow of economic factors, highly efficient allocation of resources and deep integration of markets; encouraging the countries along the Belt and Road to achieve economic policy coordination and carry out broader and more in-depth regional cooperation of higher standards; and jointly creating an open, inclusive and balanced regional economic cooperation architecture that benefits all" (Vision and Actions on Jointly Building the Silk Road Economic Belt and the 21st-Century Maritime Silk Road, 2015). In Central Asia, there are two important incentives for China to promote its BRI in the region. Firstly, China wants to appease the troubled Xinjiang region which has remains or has remained the focus of extremism in the country. Secondly, China's BRI can help Beijing attract the Central Asian economies and tie them to Beijing's economic fortune to prevent them from becoming zone of anti-China sphere of influence.

Marlene Laruelle, the Director of the George Washington University Central Asia Program, argues that BRI is not only the "sum of individual projects centered around the idea of connecting China to the rest of the world via new continental and maritime infrastructure, ... it is a meta-discourse on the Silk Road and a new manifestation of China's soft power, of its peaceful and multilateral rise" (Laruelle, 2018: 10). To promote its geopolitical profile in the region, China is interested in maximizing the utilities of BRI to the economically troubled Central Asian region, especially amidst the pandemic.

China's rapid defeat to the Pandemic at home and revival of its economy allows the economically desperate regional countries to seek their economic fortunes tied with Beijing. This also turns China towards its predetermined strategic objectives in Central Asia. Nadege Rolland, Senior Fellow at the National Bureau of Asian Research (NBAR), states that "there are no signs that the pandemic has deterred China from its long-term objectives. Beijing is still intent on seeing China rise to the top in global affairs and it sees the current disorder from the virus as a way to achieve that goal" (Standish, Coronavirus, 2020). In Central Asia, that goal is to implement the SREB and ensure greater role for China in the region. 
In its first hand of cooperation, China hosted a meeting with the Foreign Ministers of five Central Asian countries on July 16, 2020 which discussed the mechanism to respond to the Pandemic while also to restart the COVID-19 hit regional economies (Huaxia, 2020). Interestingly, all the regional countries supported the synergy between China's BRI and Central Asian development strategies to increases the benefits of cooperation in the post-Pandemic economic recovery (Huaxia, 2020). This shows willingness among Central Asian countries to welcome the BRI as instrumental to its economic recovery and growth in Post-COVID-19 situation.

\section{STRATEGIC UTILITIES OF BRI IN CENTRAL ASIA FOR CHINA}

There are three significant utilities the BRI in Central Asia offers to China.

\section{Access to European and West Asian Markets}

Central Asia is the gateway for China to connect with Europe and West Asia. Its China-Central Asia-West Asia Economic Corridor (CCAWEC) is one of the six major routes of BRI that allows China to explore the economic opportunities in European and West Asian markets. Experts believe that the Corridors will integrate markets of Central Asia, Caucasus, Turkey, the Balkans, and European Union (The Belt and Road Initiative in the global trade, 2021). Moreover, BRI also involves a railway project that connects China with Europe by passing through Kazakhstan, Russia, Belarus and Poland through a New Eurasian Land bridge. In fact, the first Chinese locomotive travelled from China to Czech Republic in November 2019 which passed through Kazakhstan, Azerbaijan, Georgia, and using Turkish Bosporus Tunnel before touching the Central Europe (Hatipoglu, Gokmen, 2019).

Regional connectivity is central to the concept of BRI which encourages regional integration and ties the economic fortune of Central Asian countries and beyond with Beijing. For instance, over the years since the BRI was announced in 2013, China's aggregate trade with the BRI countries having shown a 'robust growth' of some 10.8 percent which was estimated to be around \$1.34 trillion in 2019 (China's trade with BRI, 2019). In fact, a study has found that China's trade with BRI countries is 8 percent faster than with the non-BRI countries (Chungiiao Yu, 2020). Apart from increase in trade volume, China also benefits from the relatively lower costs of transportation as the connectivity shortens the distance e.g. distance reduced from a month to only 12 days between China and Turkey.

\section{Natural Resources}

China's unprecedented economic growth over the past three decades demands greater need for energy imports to propel its industrial growth. Today, China is the world's largest energy consumer accounting for around 20 percent of global consump- 
tion and imports more oil, coal, and natural gas than the rest world combined. The U.S. Energy Information Administration (EIA) suggests that China may need to import 75 percent of the total energy and 62 percent of oil it is expected to consume by 2035 (Tata, 2017). Central Asia along with the Caspian coast, on the other hand, accounts for 4 percent of the global energy deposits of around 17 to $33 \mathrm{bbl} /$ day. Besides the abundance of natural resources, the increased footprints in Central Asia provide China a relatively secure energy resource. Therefore, China's tilt towards Central Asia as a secure energy resource base is integral to BRI which is working on a number of pipelines to link the regional energy resources with Beijing.

Energy resources in Central Asia fall second in priority after rail and road connectivity to the Chinese BRI. By 2019, the China has announced around 48 bilateral energy related projects under BRI which includes 20 projects in Kazakhstan, 12 in Uzbekistan, 7 in Tajikistan, 5 in Kyrgyzstan, and some 4 projects in Turkmenistan (Aminjonov et al., 2019). The energy related Chinese investments stands at around $\$ 35.6938$ billion which demonstrated China's interest in the Central Asian energy reserves (Aminjonov et al., 2019). As part of China's growing interests in Central Asian energy reserves, a number of Chinese energy players are operating in the region including China National Petroleum Corporation (CNPC), China National Offshore Oil Corporation (CNOOC), China Petroleum and Chemical Corporation (SINOPEC), as well as the Petro China. These Chinese companies are cooperating with local companies to offset the influence of competing firms from Russia and the US like the Chevron and ExxonMobil in exploration and extraction of natural gas and oil. The companies have already built two important pipelines from Central Asia to China that includes the Central Asia-China gas pipeline and Kazakhstan-China oil pipelines through which the former transports around 55 billion cubic meters per annum or more than half of Turkmenistan's gas to Shanghai (Overland, 2016: 122-130).

\section{Strategic Home-Front}

Besides economic and political components, BRI has its security component which serves as China's efforts to offset the security challenges emerge from Central Asia. This includes countering the 'three evils' including terrorism, separatism, and violent extremism which threatens China's Xinjiang province. China has identified the Islamic Movement of Uzbekistan, Jamaat Ansarullah, and Islamic Jihad Union, as the major militant organizations threatening Chinese national interests (Sukhakin, 2020: 29-34). Daohang Wang, a Chinese expert, believes that Kazakhstan houses around 18 terrorist groups whereas thousands of individuals have taken part in Syrian civil war and other troubled conflicts in the Middle East and Afghanistan. China has expressed its commitment and taken a number of measures to tackle the threat.

To offset the challenges of the 'three evils', China has increased its arms deliveries to Central Asian states with 18 percent of its total sales between 2015 and 2020 (Standish, 2020). It has already conducted anti-terrorism military exercises such as the Xiezuo-2019 (Cooperation-2019) with Tajikistan in August 2019 (China, Tajikistan concludes joint anti-terrorism drill, 2019). Apart from this, China consid- 
ers the use of Private Military Contractors (PMCs) such as the Frontier Services Group (FSG) to secure its BRI related projects from terrorist attacks in Central Asia (Sukhankin, 2020: 18-24).

China realizes the socioeconomic disparities as the fundamental cause of growing extremism in the region, and therefore; China has improved its investment under BRI in wide range of socioeconomic, political, and educational sectors to improve the living standards of the people and transform the Central Asian societies. The vulnerabilities have further increased during the COVID-19 crisis given the economic challenges faced by the socioeconomically weak societies. This provides China the opportunity to enhance its image and build it profile in Central Asia as a benign actor with a vision to build a community with shared development.

The economic slowdown due to the Pandemic allows China to portray the BRI as the most viable alternative and savior of regional economies. Arne Elias Corneliussen, director of the Global Geopolitical Analysis, argues in an online conference at the Institute of War and Peace that "China may adapt its BRI strategy to meet new needs in a post-COVID-19 world to rebuild economies, [and] support local manufacturing industrial development" (China's Post-COVID-19 Palns for Central Asia, 2020). To him, Central Asia will continue to see economic growth over the coming years only because of the BRI, given its integral position to link regional markets to the world's second largest economy i.e. China. This gives China a major role in rebuilding Central Asian economies once the pandemic is over, and to advance its vital strategic interests.

Therefore, the BRI during COVID-19 is a masterstroke for China to forge close economic, political, and strategic partnerships with regional countries. This helps Beijing to counter the rival influences including that of Russia and the US, combat the anti-China extremist groups in Central Asia, cultivate regional economic dependency over Beijing, and tie down their economic and political fortunes with its ambitious BRI to achieve its long-term strategic objectives in the energy rich Central Asian region.

Together with provision of economic incentives, China has taken its 'COVID-Diplomacy' to its bloom with increasing focus to counter anti-China narrative associated to the origin of the virus (Khan, 2020). In this regard, China's diplomatic missions have been mobilized to inject its perspectives into the domestic debate in Central Asia. For instance, Chinese embassies swiftly reacted to the developing theories in Uzbekistan and Kazakhstan which considers Wuhan (in China) as the 'birth place' of the novel Coronavirus. In fact in Kazakhstan, Chinese officials even sowed the seeds of new virus which was 'much deadlier' than the COVID-19 itself; however, the virus turned out to be pneumonia (Kenderdine, 2020). Before this, China issued its official White Paper on "Fighting COVID-19: China in Action" which was to highlight the effective combat of the COVID-19 by Beijing (Full Text: Fighting COVID-19: China in Action, 2020). Such a proactive diplomatic campaign to build the narrative is part of China's COVID-Diplomacy and continuation of its efforts to deflect the blame over China as the origin of the Virus (Hashimova, 2020).

Therefore, the growing Central Asian's economic dependency over China, lack of credible alternatives, poor economic condition, and robust economic incentives offered by China keeps the Central Asian countries in close proximity to Beijing which increases the prospects for the successful implementation of BRI in the immediate af- 
termath of COVID-19. In this way during the Pandemic, China continues to get hold of the narrative as well as strengthens its economic and political position in Central Asia.

\section{Challenges to the BRI in Central Asia}

With the increasing prospects for the need of BRI as quintessential for the rapid economic recovery, the challenges posed by the COVID-19 to the BRI are also of growing concern to China and Central Asian countries. In fact for China, building this ambitious economic project is reminiscent to a Chinese saying that 'cross the river by feeling the stones'. Even before the pandemic, BRI attracted widespread criticism for its lack of transparency, adverse impact of environment, forced migration, and the dilemma of 'debttrap' for regional countries. However, the pandemic has rather added to these challenges.

Firstly, the direct impact of the travel restrictions and other containment measures taken by regional countries have seriously hampered progress over key BRI projects. For instance in June 2020, the Chinese Foreign Ministry stated that 20 percent of the Chinese projects under its BRI are "seriously affected" by the COVID-19 pandemic (China says one-fifth of Belt, 2020). Another 40 percent of the projects have also been affected with minor disruptions. The nature of these projects is infrastructural which includes railways, ports, and highways etc.

Secondly, it also declines China's ability to fund the projects in the region since Chinese banks are cautious about disbursing unsustainable loans. This has caused a sharp decrease in the Chinese investment which is mostly directed to fight the COVID-19 at home. China's Global Investment Tracker shows that Chinese investment and construction has fell sharply which was reported to be only around $\$ 6$ billion between 2019 and 2020, most of which was in the early 2019 (Scissors, 2020). Such a decline in investment though short term in nature, it nevertheless impedes progress over major BRI initiatives in Central Asia.

Thirdly, the success of the BRI is relative in practice as a huge chunk of money reserved for different projects is wasted to corruption due to the dysfunctional administrative systems in Central Asian countries with less accountability and transparency. Also, the projects announced under BRI are designed on the basis of their profitability with little attention to the sustainability which reduces their utility to the regional countries in terms of employment opportunities and technology transfer. Therefore, whatever the outcome of the impact of the COVID-19, the nature and feasibility of benefits from the BRI remains uncertain, especially for the mal-governed region like Central Asia.

Fourthly, Russia, historically the most dynamic player in the region, and its Eurasian Economic Union (EAEU) offers a limited challenge to China's BRI. Russia falls short in terms of its resources to achieve its Soviet-era greatness in a global environment where China provides alternatives (BRI etc.) to Europe and even to Russia's near abroad. Still, however, both the powers have agreed in 2015 to coordinate their ambitious geopolitical projects; yet, their use of hedging strategies against each other remains a challenge to such cooperation. Therefore, China's efforts to use BRI as part of its grand strategy to improve its geopolitical position in the region are unlikely to go unnoticed by Moscow whose EAEU is a project with similar ambitions. Yet, the ben- 
efits of EAEU and the BRI depend on the stability of the 'marriage of inconvenience' between Moscow and Beijing. Therefore for Russia a strategic partnership, if not alliance, with China is inevitable for a greater say in shaping the Eurasian order. Despite historical grievances, glaring demographic imbalance, and a growing power asymmetry, the mutual consensus between Russia and China over the future of the Eurasian order could create a bilateral condominium over the region (Rolland, 2019). Therefore, besides becoming a regional bloc competing with the developed economies, combining the strength of EAEU and the BRI could increase the 'economic discursive rights' of China and Russia to profoundly impact the geopolitics of the Central Asian region.

Fifthly, the weak regional response to the COVID-19 and poor infrastructure of Central Asian countries forestalls the BRI project which can influence the ability of the BRI in helping the region recover from the economic shocks of the pandemic. The vulnerabilities are mostly visible in health sector, and economic contraction which slows the response of governments to overcome the crisis. Also, some authoritarian regimes have concealed the factual data on COVID-19 which further complicates prospects for identification of highly affected zones and hence the recovery of the population from the Pandemic.

Despite China's huge economic, political, and security contribution, Beijing is still poorly understood as a feared country. For the last 15 years, China dominates Central Asian market as the top or second largest trading partner of all the countries in the region. However, still, the frequent demonstrations in Kazakhstan and Kyrgyzstan are evident as the new normal to oppose the 'soft expansion' of China. Such rising Sinophobic sentiments are a potential challenge to China's BRI which is seen as part of Beijing's 'creepy invasion' in the region (Peyrouse, 2020). Beijing is countering such narratives with its public diplomacy and soft power approach as part of its good neighbor policy; yet, the challenge is paramount to be sidelined in the near future.

Lastly America, as the influential and strategically relevant actor, remains the primary challenge to China's growing influence, and therefore to its BRI. Washington has criticized China's record of human rights and convinced Central Asian countries to stay 'careful' in their dealings with China. Washington is concerned about BRI as expected to threaten the Post-WW2 hegemony and enhance China's global influence vis-à-vis the United States. The US officials have time and again criticized the project as it promotes China's 'predatory economics' to intimidate regional states. Such abhorrent views towards BRI makes the US an essential threat to BRI in Central Asia as it still enjoys relatively more influence over Central Asian countries. The use of C5+1 platform to extend alternative support to regional economies is one such effort creating a wedge among the regional countries towards China's BRI.

\section{RECOMMENDATIONS}

Since the immediate challenge to the full scale revival of the BRI is the persisting Pandemic that continuous to rise with each each passing day in face of the weak response by the regional governments. China needs to accelerate support to the regional countries, especially the ones with important BRI projects, to combat the Pandemic and ensure a speedy revival of its BRI. Such a support is already in place as part of China 'Silk Road 
for Health' under the Chinese saying of 'just cause finds great support and compassion knows no border"; yet, Beijing needs to provide essential medical equipment, testing kits, and monetary support to take this essentially vital region out of the deadly pandemic. The sooner the region defeats the pandemic, the earlier the BRI activities will begin to improve China's geopolitical standing in the Post-COVID-19 Central Asia.

The dislocation of funds from the Chinese banks towards fighting the Pandemic is an important factor which slowed progress over the BRI activities in Central Asia. Now when China has successfully defeated the COVID-19 Pandemic at home, it needs to relocate those funds towards BRI projects and accelerate their progress. In fact, besides the existing allocations, China should provide additional support funds to the Central Asian governments to support their socio-economic structure so as to stay active in their efforts to undertake major projects under the BRI.

Even prior to the pandemic, China's image was vulnerable to frenzied criticism which has rather accelerated with the COVID-19 for its alleged role in spreading it around the world. Therefore, China's image as a benign actor and lack of domestic support for Beijing is a long-standing and fundamental challenge to China's presence in Central Asia. China needs to invest more in improving its soft image in the region more than it needed earlier and doing so will help China assuage regional public opinion in its favor to pave ways for China's influence in the region vis-à-vis other major peers like Russia and the U.S.

Central Asia's overwhelming economic inter-dependence over Beijing, especially during the COVID-19 Pandemic, is of equal concern to the region's strategic autonomy and political manipulation. The regional countries should be careful in welcoming Chinese investment for either being in capacity of mutual development or extension of its widely criticized 'Debt-Trap Diplomacy' as part of its 'Predatory Lending' approach. This, however, is more successful if the United States remains a credible alternative to the Chinese investment in the region. Therefore, Central Asia should look beyond China and avoid tying its economic fate to the predatory lending approach of China which can result in its economic, political, and strategic manipulation.

Lastly, Central Asian countries are growing tilting towards China given its rapid economic rise and potential of extending huge investment to the region. However, this could rather end up with China as the only source of economic health for the region with fewer prospects for other major powers like Russia and the US to maneuver. In fact, the realization that a swift embrace of China does not mean moving away from Russia or the US is the key to a long-standing economic prosperity for the Central Asian region. In fact, the region can ride multiple horses such as Russia, China, and the US at the same time to ensure continued progress and development in the post-Pandemic world.

\section{CONCLUSION}

Central Asian region is expected to slide rapidly towards China in the post-Pandemic environment were the region considers BRI as the immediate and long-term remedy for its economic recovery. In fact, the presence of the autocratic regimes in almost every regional country rather increases the given probability. The geopoliti- 
cal importance of the region leaves China more interested in the region's natural resources, its importance as the integral part of a land corridor to connect with Europe, and using the region as a strategic home-front to confront regional security challenges. Therefore, China realizes the need of using COVID-19 as an immediate geopolitical opportunity to enhance its strategic influence in the Post-COVID-19 Central Asia.

Given the need to improve its influence in the region, China has extended its BRI as well as some immediate assistance to the Central Asian countries. In this regards, the billions of dollars of investment to build energy sector, infrastructure, improve regional connectivity and use the region as the 'Buck of the Belt' to connect with Europe, in addition to bringing it closer to Beijing's economic orbit. Additionally China has improved its security cooperation with Central Asian countries by conducting regular military exercises and providing them with critical military equipment to help China fight extremism and offset their threat to China's western region, especially Xinjiang. Cooperation during the Pandemic is of critical importance which has increased with the provision of technical expertise and medical and financial support to the regional countries to fight COVID-19 and improve prospects for the revival of working on BRI projects. However, still, the project is vulnerable to a number of challenges which includes reduced funding due to COVID-19, weak regional response to the Pandemic, and other alternatives to BRI including Russia's EAEU and the US. Having said that, the success of the BRI hinges upon its ability to prospect better opportunities for the pandemic-hit Central Asian economies.

In the nutshell, Central Asia requires immediate economic recovery opportunities; however, regional countries need to assess the nature of the opportunities and cost and benefits linked to them. BRI brings economic opportunities but also tests Central Asia's political decision-making vis-à-vis other major powers like Russia and the US. Therefore, the aggregate benefit of the region is to adopt an ambivalent approach towards all the major powers including China, Russia, and the US to maximize their economic, political, and strategic interests. It means the regional countries should not trade off its relations with the US and Russia for its economic engagement with Beijing and vice versa. Instead, Central Asian countries need to take on its relations with Beijing including the BRI as complementary to its historical and multi-pronged partnership with the US. This helps the region to secure greater economic benefits from Beijing for its post-Pandemic economic recovery and also to secure its strategic autonomy with relative balance in its relations with other major powers.

\section{REFERENCES}

Akhal-Teke (2020, August 5), Turkmenistan: Hiding from Sstellites, Retrieved from Eurasianet: https://eurasianet.org/turkmenistan-hiding-from-satellites.

Aminjonov F., et al., (2019), Report. Norwegian Institute of Inernational Affairs.

Belt and Road Initiative in Central Asia and Caucasus (2019), The World Bank, Washington D.C.

Bourdieu P. (1989), Social Space and Symbolic Power. Sociological Theory, 14-25.

China says one-fifth of Belt and Road projects 'seriously' affected by pandemic (2020, June 19), Retrieved from Rueters: https://www.reuters.com/article/us-health-coronavirus-china-silkroadidUSKBN23Q0I1. 
China, Tajikistan concludes joint anti-terrorism drill (2019, August 16), Retrieved from China Military Online: http://eng.chinamil.com.cn/view/2019-08/16/content_9592237.htm.

China's Post-COVID-19 Palns for Central Asia (2020, April 22), Retrieved from Institute for War and Peace Reporting: https://iwpr.net/global-voices/chinas-post-covid-19-plans-central-asia.

China's trade with BRI countries surges to \$1.34 trillion in 2019 (2019, January 15), Retrieved from The Economic Times: https://economictimes.indiatimes.com/news/international/business/chinas-trade-with-bri-countries-surges-to-1-34-trillionin2019/articleshow/73271222. cms?utm_source $=$ contentofinterest\&utm_medium $=$ text\&utm_campaign $=$ cppst.

Chronology of China Belt and Road Initiative (2015), The State Council of People's Republic of China, Beijing.

Coronavirus economic watch: Central Asia and the Caucasus, August 2020, (2020, August 31), Retrieved from Eurasianet: https://eurasianet.org/coronavirus-economics-watch-central-asiaand-the-caucasus-august-2020.

COVID-19 in the Kyrgyz Republic: Assessing the Impact on Socioeconomic Situation and Vulnerability and Policy Responses (2020), Asian Development Bank.

Full Text: Fighting COVID-19: China in Action (2020, June 7), Retrieved from The State Council of the People's Republic of China: http://english.www.gov.cn/news/topnews/202006/07/content_WS5edc559ac6d066592a449030.html.

Gupta D. P. (2020, December 11), The Economic Impact of COVID-19 in Central Asia, Retrieved from Vivekananda International Foundation: https://www.vifindia.org/article/2020/december/11/the-economic-impact-of-covid-19-in-central-asia.

Hashimova U. (2020, August 3), China Changes Diplomatic Style in Central Asia Over COVID-19, Retrieved from The Diplomat: https://thediplomat.com/2020/08/china-changes-diplomaticstyles-in-central-asia-over-covid-19/.

Hatipoglu M., Gokmen E. (2019, November 7), First China Railway Express line train reaches Tur$k e y$, Retrieved from Anadolu Agency.

Huaxia (2020, July 16), Chinese FM C+C5 foreign ministers video meeting, Retrieved from Xinhuanet: http://www.xinhuanet.com/english/2020-07/16/c_139218224.htm.

Ibragimova K. (2019, October 30), Tajikistan approves Chinese \$360 million grant for highways, Retrieved from Eurasianet: https://eurasianet.org/tajikistan-approves-chinese-360-milliongrant-for-highways.

Karlis T., et al. (2019), The Belt and Road Initiative: A Geopolitical Analysis, IAM 2019 Conference (p. 7), IAM, Athens, Greece.

Kenderdine T. (2020, July 11), China Missteps with Wild Allegation of a 'New' Deadly Pneumonia in Kazakhstan, Retrieved from The Diplomat: https://thediplomat.com/2020/07/china-missteps-with-wild-allegation-of-a-new-deadly-pneumonia-in-kazakhstan/.

Khan F. (2020, April 23), COVID-19 Outbreak: Geopolitical Tiderbox, Retrieved from The Frontier Post: https://thefrontierpost.com/covid-19-outbreak-geopolitical-tinderbox/.

Laruelle M. (2018), China's Belt and Road Initiative and Its Impact on Central Asia, Central Asia Program, Washington D.C.

Overland I. (2016), Energy: The missing link in globalization. Energy Research in Social Sciences: $122-130$.

Peyrouse S. (2020, May 1), Understanding Sinophobia In Central Asia, Retrieved from The Diplomat: https://thediplomat.com/2020/04/understanding-sinophobia-in-central-asia/.

Radjabov B. (2020, June 4), Post-COVID-19: Challenges and Opportuntiies for Central Asia, Retrieved from Central Asia-Caucasus Institute: https://www.cacianalyst.org/publications/ 
analytical-articles/item/13622-post-covid-19-challenges-and-opportunities-for-central-asia. html.

Report of the State Committee o Republic of Uzbekistan for Statistics (2020), State Committee Republic of Uzbekistan, Tashkent.

Scissors D. (2020, July 16), China's Global Investment Vanishes under COVID-19, Retrieved from American Enterprise Institute: https://www.aei.org/research-products/report/chinas-globalinvestment-vanishes-under-covid-19/.

Sim L.-C., Aminjonov F. (2020, February 1), Potholes and Bumps Around the Silk Road Economic Belt in Central Asia. The Diplomat.

Standish R. (2020, May 28), China Seen as Rising Military Power in Central Asia, Forshadowing Future Friction with Russia, Retrieved from Radio Free Europe: https://www.rferl.org/a/ china-seen-as-rising-military-power-in-central-asia-foreshadowing-future-friction-withrussia/30639964.html\#: :text=This\%20shift\%20can\%20be\%20seen,to\%202014\%2C\%20 the $\% 20$ report $\% 20$ says.

Standish R. (2020, July 26), Coronavirus Crisis Accelerates China's Grab for Power, Influence in Central Asia, Retrieved from Radio Free Europe: https://www.rferl.org/a/coronavirus-crisisaccelerates-china-s-grab-for-power-influence-in-central-asia/30747653.html.

Sukhakin S. (2020), The Security Component of the BRI in Central Asia, Part One: Chinese and Regional Perspectives on Security in Central Asia, China Brief: 29-34.

Sukhankin S. (2020), Chinese Private Security Contractors: New Trends and Duture Prospects, Chna Brief: 18-24.

Tata S. (2017, January 14), Deconstructing China's Energy Security Strategy, Retrieved from The Diplomat: https://thediplomat.com/2017/01/deconstructing-chinas-energy-security-strategy/.

The August issue of the "Export Review" was presented (2020, August 31), Retrieved from CAERC: http://iqtisadiislahat.org/news/ixrac_icmali_nin_avqust_sayi_teqdim_edilib-1014.

The Belt and Road Initiative in the global trade, investment and finance landscape (2021, February 17), Retrieved from OECD Business and Finance Outlook 2018: https://www.oecd-ilibrary. org/finance-and-investment/oecd-business-and-finance-outlook-2018_9789264298828-en.

Vangeli A. (2018), Global China and Symbolic Power: The Case of 16+1 Cooperation, "Journal of Contemporary China": 674-687.

Vision and Actions on Jointly Building the Silk Road Economic Belt and the 21st-Century Maritime Silk Road (2015, March 28), Retrieved from Ministry of Foreign Affairs of the People's Republic of China: https://www.fmprc.gov.cn/mfa_eng/zxxx_662805/t1249618.shtml.

Yellinek R. (2020, February 26), The Impact of China's Belt and Road Initiative on Central Asia and South Caucasus, Retrieved from CSS Blog Network: https://isnblog.ethz.ch/trade/theimpact-of-chinas-belt-and-road-initiative-on-central-asia-and-the-south-caucasus.

Yu C. (2020, August 20), Has China's Belt and Road Initiative Intensified Bilateral Trade Links Between China and the Involved Countries?, Sustainability MDPI: 3.

\begin{abstract}
COVID-19 brings a momentous decline for global economic activities but its consequences for China's Belt and Road Initiative (BRI) remains imminent. Despite the economic shocks of the Pandemic, BRI remains a top priority for China which allows Beijing to improve regional connectivity and expand its economic outreach far off to Europe and the American shores. On the other hand, the Central Asian economies are hard hit by the pandemic with a reduced
\end{abstract}


regional trade, decline in oil prices and its commodities, deep slump in remittances, and the slackening manufacturing ability. The revival of BRI and its immediate success is desirable to the COVID-19 hit Central Asian economies. This is because BRI has bound the region together in terms of infrastructural development where China, under the rubric of BRI, is spearheading major developmental projects, pouring investment in energy sector, offering debt, and improving bilateral trade with regional economies. For this reason, the Central Asian countries desire immediate revival of close economic cooperation which could links the economic fortunes of regional countries to Beijing and brings the BRI to the fore in regional priorities. The paper highlight the impact of COVID-19 over Central Asian economies, the significance BRI for the region; its geopolitical importance for China; and the growing Chinese influence in the postPandemic Central Asia using Bourdieu's Theory of Symbolic Power. Finally, using qualitative content analysis, the paper argues that the economic impact of COVID-19 are short-term and of limited nature and it will only increase prospects for BRI in the post-Pandemic Central Asia with vital strategic utilities for China's geopolitical profile in the region.

Keywords: BRI, China, Central Asia, COVID-19, Trade, Kyrgyzstan, Uzbekistan, geopolitical significance.

\section{PERSPEKTYWY CHIŃSKIEGO BRI I WPLYWY STRATEGICZNE W AZJI ŚRODKOWEJ W EPOCE POST-COVID-19}

\section{STRESZCZENIE}

COVID-19 przynosi doniosły spadek globalnego rozwoju gospodarczego, a jego konsekwencje dla chińskiej inicjatywy Belt and Road Initiative (BRI) pozostają także nieuchronne. Pomimo wstrząsów gospodarczych pandemii, BRI pozostaje głównym priorytetem dla Chin, co pozwala Pekinowi poprawić łączność regionalną i rozszerzyć zasięg gospodarczy na Europę i amerykańskie wybrzeża. Z drugiej strony, pandemia mocno dotknęła gospodarki Azji Środkowej, w związku z ograniczeniem handlu regionalnego, spadkiem cen ropy naftowej i jej towarów, głębokim spadkiem przepływów pieniężnych oraz słabnącą zdolnością produkcyjną. Ożywienie BRI i jego natychmiastowy sukces jest pożądany. Dzieje się tak, ponieważ BRI połączył region w zakresie rozwoju infrastruktury, gdzie Chiny, pod nazwą BRI, inicjują duże projekty rozwojowe, inwestując inwestycje w sektor energetyczny, oferując zadłużenie i poprawiając dwustronny handel z regionalnymi gospodarkami. Z tego powodu kraje Azji Środkowej pragną natychmiastowego ożywienia oraz bliskiej współpracy gospodarczej, która mogłaby powiązać losy gospodarcze krajów regionalnych z Pekinem i wysunąć BRI na pierwszy plan w priorytetach regionalnych. Artykuł podkreśla wpływ COVID-19 na gospodarki Azji Środkowej, znaczenie BRI dla regionu; jego geopolityczne znaczenie dla Chin; oraz rosnące wpływy chińskie w post-pandemicznej Azji Centralnej za pomocą teorii siły symbolicznej Bourdieu. Wreszcie, korzystając z jakościowej analizy treści, artykuł argumentuje, że wpływ gospodarczy COVID-19 jest krótkoterminowy oraz ograniczony, i tylko zwiększy perspektywy dla BRI w post-pandemicznej Azji Środkowej, z istotnymi strategicznymi narzędziami dla profilu geopolitycznego Chin w regionie.

Słowa kluczowe: BRI, Chiny, Azja Centralna, COVID-19, Handel, Kirgistan, Uzbekistan, znaczenie geopolityczne 
